\title{
Modernization of Education Contents of Muhammadiyah, Nahdlatul Ulama, and Al Jam'iyatul Washliyah 1900-1942 in North Sumatera
}

\author{
Dr. Solihah Titin Sumanti, M.A ${ }^{\# 1,}$ Prof. Dr. Hasan Asari, M.A ${ }^{\# 2,}$ Prof.Dr. Al Rasyidin, M.Ag \#3 \\ ${ }^{1 \#}$ Lecturer Faculty of Social Science, UIN North Sumatra \\ ${ }^{2}$ \# Lecturer Faculty of Tarbiyah and Teachers Training UIN North Sumatra \\ ${ }^{3 *}$ Lecturer Faculty of Tarbiyah and Teachers Training UIN North Sumatra \\ Jl. Williem Iskandar Pasar V Medan Estate 20371, Sumatera Utara Indonesia
}

\begin{abstract}
This study aims to reveal how the process of modernization of education content on the organization Muhammadiyah, Nahdlatul Ulama and Al Jam'iyatul Washliyah years 1900-1942. The issues raised are: (1) how the historical background in modernizing education content of the three organizations; (2), how the modernization process of these organizations to arrange their education content; (3), how the these organizations dissemination of education content on the subjects. This is solved by historical method comprising the steps of: heuristics; second, verification; interpretation; historiography, and social history. The findings research informs: First, the three organizations have the same background in determining the education content, those are, first; the spirit leaders spreading Islam in accupation situation by orienting on Islamic education of the occupation, second; the intellectual contact internally an externally to conceive and build on the progress of Islamic education. Third; The strong desire to equate Islamic education progress with the western progress (colonization), fourth; The desire to realize the equality social among communities in receiving education and the world of work. The second finding is; the same formulate of education content material Islamic teaching that originated from $A D$ and $A R T$, but have different ways depending on modern education content. Muhammadiyah with revolutionary and Nahdlatul Ulama with evolutionary, and Al Jam'iyatul Washliyah with situasionery. the third finding is; the similarities of education content modernization process using a common and religious material. However they have differences on the distribution of the content in the subjects, Muhammadiyah is innovative and NahdlatulUlama is creative and Al Jam'iyatul Washliyah is very selective.
\end{abstract}

Keywords: Modernization, Education Contents, Muhammadiyah, Nahdlatul Ulama, Al Jam'iyatul Washliyah

\section{INTRODUCTION}

Islamic education in Indonesia goes hand in hand with the entry of Islamic teachings in Indonesia. The process of spreading Islamic teachings in the community influences the implementation of local education that encourages the emergence of Islamic schools in Indonesia, for example, islamic boarding school (pesantren). ${ }^{1}$ As the times progressed, Islamic education in Indonesia was challenged by modernity and postmodernity. Islamic education in the context of modernity is faced with industrial markets and in the context of postmodernity, Islamic education is faced with the utilization of information technology which resulted in the necessity to review the contents of Islamic education in Indonesia. ${ }^{2}$

Structuring and reviewing the content of education, indicating that there has been a historical development that led to organizational leaders in developing educational content that moves individually or in groups. The important point in this regard is the unification of Western education brought by foreigners in Indonesia, with Islamic education. Such circumstances result in Islamic values being fundamental to the development of Islamic education materials throughout its journey as it is applied in the teaching sciences of Islamic schools.

Islamic education materials are formed as Islamic sciences and applied to the subjects. The third process is called the content of Islamic education in this study. Educational content is used by researchers to describe the development of teachings into educational materials. The manifestation of the teaching becomes the science that enters in the School by loading the materials in the subjects. The content of this education summarizes all such processes from the emergence of the teachings to the 
availability of materials and into the sciences that are disseminated as subjects.

In the classical era the development of Islamic education content takes its place on the model of Islamic School with the advent of classifying the sciences in Islam. At the time of the Abbasyiah empire. These sciences stand on their own and slowly enter Indonesia which was then called by Nurcholish Madjid $^{4}$ as a traditional Islamic discipline that includes the science of Kalam, fiqh, Tasawuf and the science of philosophy. These Islamic sciences are part of the content of Islamic education that survived until the early 20th century. In this century, the content of Islamic education is once again confronted with the content of education brought by Western civilization. The contents of Islamic education are in touch, which continues to roll and pull between the contents of Islamic education with the content of Western education.

The development of the content of Islamic education is important to be expressed in this study, because sooner or later the content of this education fills almost all Islamic schools in the modern age. Formulation of educational content is in need of organization figures in one community is an organization that has a vision and mission and the same goal in delivering Islamic education materials. This interest and desire in this quest became the background of this research to see further experiment of science materials used by three organizations namely Muhammadiyah, Nahdlatul Ulama and Al Jam'iyatul Washliyah in the era of 1900-1942. Thus, the focus of this research study, how big the activities of Muhammadiyah organization leaders, Nahdlatul Ulama and Al Jam'iyatul Washliyah in modernizing the contents of Islamic education and the development of materials science at that time.

The Nahdlatul Ulama Organization, established in 1926, utilizes Pesantren as a School by maintaining the heritage of Islamic tradition. However, in its development, Pesantren also experienced a change in the content of education, as well as the organization al Jam'iyatul Washliyah which was established in 1930 with the School named Madrasah Diniyah al Jam'iyatul Washliyah in 1932, trying to put the two science materials in the school he founded to remain walking all the time. The state of education in Indonesia at the time was still dominated by Dutch schools. But these schools can not accommodate many lower-class indigenes. Such circumstances then led Ahmad Dahlan with his organization, Muhammadiyah who initiated the school for all the indigenous community at that time.

Departing from the issues that emerged above that the modernization of the content of Islamic education into interesting discourse to be examined when there is attraction between religious materials as Islamic teachings with the common materials brought by Western education (colonizers). The development of religious materials is fertilized through schools and supported by Islamic organizations that occurred in 1900-1942, so that the teachings of Islam have been preserved to this day. This reason, has made Muhammadiyah organization, Nahdlatul Ulama and Al Jam'iyatul Washliyah have a sense of responsibility towards the development of Islamic teachings in Indonesia.

This study uses a social history approach with the focus of research conducted on the experimental use of subjects in Muhammadiyah, Nahdlatul Ulama and Al Jam'iyatul Washliyah in 1900-1942. Research on Islamic organizations is generally studied separately from each of these Islamic organizations and is always closer to the views of its assessment on many aspects of education such as research dissertation conducted Zul Asyri ${ }^{5}$ entitled Nahdlatul Ulama: Studies of Religious Understanding and Conservation Efforts through Schools Pesantren, Dja'far Siddik's dissertation which discusses the Muhammadiyah Islamic Education Concept: Systematization and Interpretation based on Educational Science Perspective, and a Chalijah Hasanuddin work entitled: Al Jam'iyatul Washliyah 1930-1942 Fire in the Chaff in East Sumatra. The research method used in this work is the historical method, with the approach of social history of education.

\section{DISCUSSION}

\section{A. Background Modernization of Islamic Education in Indonesia}

The political journey in Indonesia when traced back to the 2nd century until the 12th century once had political power both in the days of the Hindu-Buddhist kingdom and the Islamic kingdom. The contiguity of these three cultures will influence the development of simple science in Indonesia becomes more complex, especially after the entry of Western culture in the 9th century. The time span of the 9 th century to the $12 \mathrm{H}$ Indonesian has had many works of literature. Among others are The history of Malay and the works of mysticism composed by Hamzah Fansuri of Sumatra (w.1590) are his works entitled: Syarāb al-'asyiqīn, Syamsuddin of Pasai (w.1630) with the work of Nūr ad- daqā'iq, Nur alDin Ar-Raniniri of Gujarat (w.1658) with works: Bustān as Salātīn, and Abdurrauf of Singkil (w.1690). ${ }^{6}$ In addition to Tasawuf, tarekat also has an important role in introducing Islamic teachings, especially among Pesantren. ${ }^{7}$ In addition, there are also several other disciplines that also developed, in Islamic schools before the 19th century, such as science Fikih, Tafsir, Hadits, Aqidah and Tauhid.8 
When the gouvernement has full power over the Indonesian colony, the contiguity of the religious sciences with the general sciences is inevitable. This incident occurred, until the early 19th century, which is marked by the influx of influential movement movements that are the impact of the presence of contact between Indonesia and the Islamic State in the Middle East and Europeans in Indonesia at that time. The European nation in Indonesia at that time mapped the Indonesian people into two groups, namely social groups and in the class of intellectual thought. The classification resulted in the existence of social class that had an impact on the occurrence of discrimination in the field of education among indigenous peoples from the lower classes.

Such circumstances, making the Netherlands to apply the policy of ethical politics ${ }^{9}$ at the beginning of the 20th century which is a concern for indigenous education that aims for the welfare of indigenous communities at that time. ${ }^{10}$ But in its development, the policy is increasingly cornering the position of Muslims. ${ }^{11}$ Therefore in the 20th century, the Indonesian Muslim community (indigenous and non-indigenous) get a fresh impetus from the enhancement of relationships with Islamic centers in the Middle East which will lead to the renewal of education in Indonesia. The contact between Muslims in Indonesia and Muslim countries in the Middle East was established through the implementation of the Hajj, and has increased since the opening of the Suez Canal in Egypt in 1869. While in Java the community of Muslims is divided into abangan, priyayi and santri groups as in the book Clifford Geertz. ${ }^{12}$

The situation then resulted in many great scholars who are very influential in Indonesia. Among were Shaykh Ahmad Khatib (1860-1916), Sheikh Nawawi al-Bantani (1813-1897) and Shaykh Ahmad al-Fattani (1869-1908). These three figures have many students almost all over Indonesia.

The modernization of educational contents in Indonesia is a change due to the existence of different cultural elements and spread among the local community. At the beginning of the 20th century was the success of the invaders doing experiments on the spread of Western culture through education, namely the establishment of Dutch schools in Indonesia, such as HIS, MULO, AMS. ${ }^{13}$

With the establishment of Dutch schools, education in Indonesia became uneven. In addition, Islamic education among Indonesian society at that time also experienced discrimination. This is then one of the factors of growing desire among Muslims to advance Islamic education in Indonesia. The spirit of Muslims is one of them is evidenced by the establishment of Islamic schools, such as Adabiyah School in 1905 containing materials of religious sciences and general sciences in Minangkabau and
Diniyah School founded by Ahmad Dahlan with the same science character with Adabiyah School School.

As explained earlier, that the contiguity of Indonesia with the Islamic countries in the Middle East is also an important factor in the emergence of modernization of education in Indonesia. In addition, the spirit of renewal that occurred in Egypt, Turkey, and India in the 20th century, also became an important factors in the modernization of education in Indonesia.

Broadly speaking there are four factors that encourage the attitude of Muslims in modernizing Islamic education in the 20th century, the first; factor pragmatic needs of Muslims at that time. Secondly, there is an order in Islam to foster science. Third, the historical heritage factor of Muslims is very rich in the treasury of science. Fourth, the Muslim contact with the Western world in the 18th and 19th centuries.

\section{B. Muhammadiyah, Nahdlatul Ulama and Al Jam'iyatul Washliyah's attitude on the Modernization of Islamic Education}

Moehammadijah $^{14}$ is a social organization with an educational orientation. This is evidenced by the birth of Muhammadiyah on 18 November $1912 \mathrm{M}$ in Yogyakarta ${ }^{15}$ starting with a school founded Ahmad Dahlan, he also the initiator of the establishment of the Muhammadiyah Organization. Leadership in Muhammadiyah from 1912-1942 was: Ahmad Dahlan (w.1923), Ahmad Ibrahim (w. 1932), Hisham (w.1936) and Mas Mansur (w. 1946). Muhammadiyah's lunge in the world of education is oriented towards the modern schools they founded.

Nahdlatul Ulama $^{16}$ is one of the social organization of religion and society which contribute in the development of education in Indonesia which was established on January 311926 in Surabaya coincide 16 Radjab $1344 \mathrm{H}$, with the proposal letter dated 5 September 1929 to the government then got Rechtspersoon from gouvernement of the Dutch East Indies on February 61930 with no. Ix. ${ }^{17}$ The pioneer of this organization was founded by Hashim Asy'ari and Abdul Wahab Hasbullah (w.1950). Nahdlatul Ulama lunge in the field of education will be more prioritized through salaf pesantren.

Organization al-Jam'iyatul Washliyah ${ }^{18}$ was established on 30 November 1930, is the youngest organization compared to Muhammadiyah and Nahdlatul Ulama. The success of al Jam'iyatul Washliyah in developing the education of Muslims in East Sumatra was a lengthy undertaking undertaken by the founding of schools until 1942 . 


\section{Contents of Education and Its Affecting Factors}

The push for reform in Islam that occurred in the Middle East triggered the intellectuals of Muslims in Indonesia, especially the leaders of organizations who have been involved directly or indirectly with reformers in Egypt, Turkey and India. The intellectuals of Islam make education as a momentum to improve the children of the nation who have a high awareness in escape from colonialism.

Organization became one of the institutions that play a role in the modernization of education that occurred in Indonesia. among them are the three organizations mentioned earlier. The content of educational materials within Muhammadiyah is determined from the direction of Dutch policy orientation on education at the beginning of the 20th century. Muhammadiyah has a way of managing its school in a modern way following the Dutch education pattern. Muhammadiyah's attitude thus shows Muhammadiyah's cooperative with the Dutch in running its school system so that there is no difficult relationship between the two in advancing education.

At the beginning of the formation of schools Nahdlatul Ulama actually fill the contents of the material with Islamic teachings that already exist and maintained to remain preserved. However, the material content arises not solely because of the gouvernement policy but the need factor of the intellectuals of Nahdlatul Ulama. However, in its development, this organization also experienced contact with the education system brought by the Dutch at that time. Al Jam'iyatul Washliyah with his characters does not necessarily use the pattern of his education with Dutch colonialism. Initially $\mathrm{Al}$ Jam'iyatul Washliyah gave only religious material content in the school, but did not take a long time in the process, these figures made the preparation of their educational content by placing a general content on the school Al Jam'iyatul Washliyah.

Changes in educational content occurred when Muhammadiyah saw schools run by gouvernement, Ahmad Dahlan's activeness in the organization and his participation as a teacher who taught at gouvernement school. The content of education initiated by this organization is by developing religious lessons and then followed by general lessons. The contents of education at the Muhammadiyah School containing the materials with religious and general lessons on June 12, 1912, Muhammadiyah applied for permission to the gouvernement. Applying for the permit gets a good reception on the grounds that the contents of education is modern. Therefore, the Director of Education and Religious Affairs issued a bill which gave the authority to provide subsidies to Muslim Schools. The early Muhammadiyah schools provided general lessons in addition to Islamic religious lessons. ${ }^{19}$

In its development, Muhammadiyah also established a boarding school which became known as Muhammadiyah cottage in $1921 .^{20}$ This Muhammadiyah cottage uses a class system programmed with a five-year school that contains general subjects and religious subjects. Muhammadiyah policy with the establishment of several institutions in hoofdbestuur Muhammadiyah in the 1920s namely the institutions Sekolahan, institutions Tabligh, Taman Pustaka institutions, and institutions PKO. In the year 1923 before the death of Ahmad Dahlan has established pilot Kweekschoolnya Muhammadiyah with the help of Sosrosugondo, Djojosoegito and Wahid Hasyim.

Modernization of educational content of Nahdlatul Ulama is more intensively conducted by Wahid Hasyim, his son Hashim Asy'ari. Treat an intensive Nahdlatul Ulama on the creation of learning materials at his school, solely for Nahdlatul Ulama schools to flourish. The development of educational content that occurred in Nahdlatul Ulama was not as fast as in Muhammadiyah organization because in the development of Islamic science material in the early days of Nahdlatul Ulama establishment still dominate in school. The process of applying learning materials conducted in Pesantren on religious materials is important to be mastered in understanding the teachings of ahlussunah wal jama'ah in Nahdlatul Ulama. Therefore, presenting the general materials into a way that does not occur directly but gradually.

Dedicated Nahdlatul Ulama organization leader in religious learning materials with several books that thick, making learning religion Nahdlatul Ulama chose the orientation to maintain the traditionalist learning embodied in salaf pesantren. This situation is the cause of the unthinkable of other materials to be studied like the general sciences.

The most modernist leader of Nahdlatul Ulama in education before Wahid Hashim was Abdul Wahab Hasbullah who was a friend of Hasyim Asy'ari who was involved in the initial stewardship of the Nahdlatul Ulama organization. Abdul Wahhab emphasized religious education can be more advanced if it follows the pattern of learning with the class system as happened in Modern Schools at the beginning of the 20th century. In addition Abdul Wahhab realize that because of the conflict situation to the understanding of Islamic teaching between bermazhab with no bermazhab then he said to make the Islamic material more profoundly understand it and strengthen the studies of theology in the teaching of religion then the Madrasah established Abdul Wahhab only teach religion and not so heed with the general materials as applicable to the School of 
gouvernement or other modern schools such as the done Muhammadiyah.

The establishment of Nahdlatul Ulama shows that its educational activities on the one hand have schools with the form of Pesantren and the other in the form of Madrasah. Both forms of this school that regulate the learning system Nahdlatul Ulama including educational content used Nahdlatul Ulama. Nahdlatul Ulama School began to apply its educational content following the development of teaching materials in the year 1935 since the establishment of Madrasah Nizamiyah. Pesantren which still maintain the learning process of sway and sorogan in teaching its learning, so Madrasah on one side which is in Pesantren and can stand alone or school outside Pesantren like school which founded Abdul Wahab Hasbullah. Madrasah is doing the learning process with the classical system with religious materials and general. Thus the type of education of Pesantrens and Madrasahs has a religious school type so that in the early days the content of Nahdlatul Ulama education was only oriented to the religious sciences although the learning management was more modern. While the next development of the school gradually follow the application in a modern school.

In 1940, since the establishment of the Ma'arif department, which is the department of Nahdlatul Ulama Education, in the sustainability and progress of Madrasah Nahdlatul Ulama, Wahid Hasyim divided the Madrasah into the first; Public Madrasah consisting of: Madrasah Awwaliyah. Madrasah Ibtidaiyah, Madrasah Tsanawiyah, Madrasah Mu'allimin Wusta, Madrasah Mu'allimin 'Ulya. Then second; Special Madrasahs for High School students in developing their specialized knowledge consist of Madrasah Qudat (law), Tijarah (Economi) Madrasah, Madrasah Nijarah (Forestry), and Madrasah Zira'ah (Agriculture).

Al Jam'iyatul Washliyah with various opinions among his organizers conducted experiments by trying to formulate the content of his education through the school he founded in East Sumatra. It is important that the formulation of the content of the education will be part of Al Jam'iyatul Washliyah teaching material that has a place and is managed by Al Jam'iyatul Washliyah organization to be more advanced. The contents of education is directed to the objectives of the organization $\mathrm{Al}$ Jam'iyatul Washliyah built through the Articles of Association.

This Islamic educational material became an experiment in the first school founded by $\mathrm{Al}$ Jam'iyatul Washliyah in 1932 namely School with the name maktab al-Djamiatoel Washliah. In this maktab this religious material into the content of education $\mathrm{Al}$
Jam'iyatul Washliyah taught about the science of Islam, a matter of worship in teaching Fikih, Arabic (Nahu and Sharaf) and recitation of the Qur'an, as well as branches - other branches of Islamic sciences such as Tafseer and Hadith science. The Maktab has not taught the general sciences as in its leaflets at the time of admission of the new pupil mentioned in Chalijah Hasan's book. ${ }^{21}$

In the leaflets that his learning in $\mathrm{Al}$ Jam'iyatul Washliyah there are although not yet clear, because the level of intelligence of students in accepting the learning so that can move or go to class. Based on this level of teaching materials $\mathrm{Al}$ Jam'iyatul Washliyah formulated in the leaflets.

In the same year that the End of 1932 school Al Jam'iyatul Washliyah experiencing with the school system that has a level of education Tajhizi 2 years and Ibtidai 4 years.

\section{Distribution of Subjects in Education Muhammadiyah, Nahdlatul Ulama, and Al- Jam'iyatul Washliyah}

The development of Muhammadiyah education content from 1912 to 1942 can be seen from each type and type of Muhammadiyah School that has been established. In the type and type of school classroom visible visible, so it is very decisive material that is arranged in some subjects delivered at the level of each class. The subjects used in each class in Muhammadiyah are as follows: If the first grade school the material is: Islam, drawing, writing, arithmetic, and reading. Meanwhile, if the school is in the second grade then the material taught is: Islam, reading in its own language or with Malay or Arabic or Latin, studying one of the European languages, counting, writing, and drawing.

Nahdlatul Ulama oriented its education to schools in the form of Pesantrens and Madrasahs. Both forms of school Nahdlatul Ulama this shows the learning material is dominated religious materials, because understand mazhab in Nahdlatul Ulama. This can be seen by building the educational contents packed Nahdlatul Ulama in Pesantren.

The presence of Al Jam'iyatul Washliyah school can not be separated by the existence of science that surrounds the people in the organization. The characters al Jam'iyatul Washliyah became the most important teacher in delivering the subject matter in his school. In the management of $\mathrm{Al}$ Jam'iyatul Washliyah's educational organization is not different from the Muhammadiyah organization that in the school Al Jam'iyatul Washliyah contains the same general sciences in Muhammadiyah as mentioned Chalijah Hasan ${ }^{22}$ in his research. 
In general, the sciences used al Jami'iyatul Washliyah on normaal school. If observed the amount of knowledge used al Jam'iyatul Washliyah in the School more general use of science than his religious knowledge, with an estimated 11 general subjects are obtained while the science of religion is only 6 subjects from 17 subjects offered. The subjects owned by Al Jam'iyatul Washliyah in normaalschool have similarities although not exactly in the number of subjects used. Normalschool is a type of public school because it has more general subjects.

The dissemination of Al Jam'iyatul Washliyah's educational content based on material to be taught in 1932, at his first school, ${ }^{23}$ shows his educational content based solely on the religious sciences. The science consists of teaching materials based on the ingenuity of the students who attend school at Al Jam'iyatul Washliyah, not because of the level but based on the mastering of material provided such as;

1. Starting from reading Alif, Baa, Taa and the end.

2. Starting from the study of the Qur'an and related to Tajwid.

3. Starting from the teaching of Language, Nahu and Sharaf plus teaching the fardhu a'in.

4. Read the books to convey such understandings Fikih.

5. Read the Qur'an and Hadits, Tafsir.

\section{CONCLUSION}

In the period 1900-1942, Muhammadiyah, Nahdlatul Ulama and Al Jam'iyatul Washliyah determine the content of their education by considering several factors.First, the situation and conditions of society against the demands of Islamic teachings as the spirit of fundamental teachings in filling the organization's education contained in the AD / ART. Secondly, the existence of a massive renewal, both external pengaru brought by foreigners who come to Indonesia or internally, namely the people of Indonesia itself who wants the intellectual development. Third, the influence of the policy on education issued by the Dutch. Fourth, the economic demands of Islamic society at that time the intellectuals of various social groups want to get decent work facilities. Thus the demands of changing the existing subject matter in Islamic schools are very likely to occur and be defined as the educational content imposed in the schools of the three organizations.

The formulation of the educational content that these three organizations built during their historical journey that began in 1900-1942 has a variety of different types and types. Muhammadiyah in the formulation of the content of his education made the Islamic religious material important and as important as the materials of the general sciences which adopted the revolutionary to be applied in the content of his education. While Nahdlatul Ulama in the formulation of the content of education make the material of Islamic sciences is much more important and get serious attention although not ignore the general sciences use it gradually, thus formulation of the content of education is more evolutionary to set in the organization. While Al Jam'iyatul Washliyah, an organization that learns from both Muhammadiyah and Nahdlatul Ulama, the contents of his education set both the science by looking at which aspects are preferred and emphasized. The religious material and the general material gets its place on the content of $\mathrm{Al}$ Jam'iyatul Washliyah education selectively adapted to the situation and condition and its needs.

All three organizations establish educational content by passing it on subjects in schools. Muhammadiyah always puts and is very brave to make the general material gets a high percentage for the subjects than the subjects of religion. While Nahdlatul Ulama in educational content shows religious material is placed in a high percentage of general general material although in the end in its development the general materials become as much as religious material as it is able to create the content of its education by incorporating the general materials in Pesantren. Unlike the case of Al Jam'iyatul Washliyah, the situation of educational content that has been done by its previous organization made it has no choice but to determine with the right choice to formulate its educational content.

\section{REFERENCES}

[1] Journal of Soeara Moehammadijah, no. 1 year 1922.

[2] Journal of Soeara Moehammadijah, no. 8 years 1923.

[3] Journal Soeara Moehammadijah, no.10 of 1923.

[4] Journal of Soeara Moehammadijah, no. 4 years 1924

[5] Journal of Soeara Moehammadijah, no. 2 years 1925.

[6] Journal of Soeara Moehammadijah, no. 1 year 1934

[7] Journal of Soeara Moehammadijah, no. 6 years 1937.

[8] Journal of Soeara Moehammadijah, no. 8 years 1940.

[9] Journal of Soeara Moehammadijah, no. 11 of 1940

[10] Statuten Moehammadijah in 1912.

[11] Statuten Moehammadijah in 1914

[12] Sulaiman, Nukman, Peringatan al Djamijatul Washlijah 1/4 Abad, Medan: Pengurus Besar Al Jam'iyatul Washliyah, 1956.

[13] Statuten/Anggaran Dasar Nahdlatoel Oelama Tahun 1926.

[14] Haishoudelijk Reglement /Peraturan Rumah Tangga Nahdlatoel Oelama tahun 1926.

[15] Hasil Kongres Nahdlatoel Oelama ke 10 tahun 1935

[16] Jurnal Berita Nahdlatoel Oelama no.18, thn. Ke-5, tahun 1936.

[17] Jurnal Berita Nahdlatoel Oelama no.19, thn. Ke-5, tahun 1936

[18] Atjeh, Aboebakar, Sejarah Hidup K.H.A. Wahid Hasjim dan Karangan Tersiar, Jakarta: Panitia Peringatan almarhum K.H.A Wahid Hasjim, 1957.

[19] Salam, Junus, K.H.A Dahlan: Amal dan Perjuangannya, Djakarta: Depot Pengadjaran Muhammadijah, 1968.

[20] Salam, Solichin, K.H Hasjim Asj'ari: Ulama Besar Indonesia, Djakarta: Djajamurni, 1963.

[21] Yunus, Mahmud, Sejarah Pendidikan Islam di Indonesia, cet.2, Jakarta: Mutiara, 1979.

[22] Achmadi, Ideologi Pendidikan Islam: Paradigma Humanisme Teosentris, cet.2, Yogyakarta: Pustaka Pelajar, 2010. 
[23] Alam, Zafar, Islamic Education Theory and Practice, New Delhi, Adam Publishers and Distributors, 2002.

[24] Alfian, Politik Kaum Modernis: Perlawanan Muhammadiyah dalam Kolonialisme Belanda, Jakarta: al Wasath Publisshing House, 2010.

[25] Ali, Abd. Mukti, Konstruksi Pendidikan Islam Belajar dari Kejayaan Madrasah Nizamiyah Dinasti Saljuk, Bandung: Citapustaka Media, 2007.

[26] Anam, Chairul, Pertumbuhan dan Perkembangan NU, cet.3, Surabaya: Duta Aksara Mulia, 2010.

[27] An-Nahidl, Nunu Ahmad, et.al., Posisi Madrasah dalam Pandangan Masyarakat, cet.1, Jakarta: Gaung Persada Press, 2007.

[28] Ankersmit, F.R., Refleksi tentang Sejarah, Pendapat-pendapat Modern tentang Filsafat Sejarah, terj. Dick Hartoko, cet.1, Jakarta: Gramedia, 1987.

[29] Ardana, I Ketut, "Pergerakan Nasional dan Sistem Kepartaian," dalam Taufik Abdullah dan A.B. Lapian (ed), Indonesia dalam Arus Sejarah: Masa Pergerakan Kebangsaan, cet.1, Jakarta: P.T Ichtiar Van Hoeve dan Kementerian Pendidikan dan Kebudayaan R.I, 2012, jilid V.

[30] Asari, Hasan, Menguak Sejarah Mencari Ibrah, cet.1, Bandung: Citapustaka Media, 2006.

[31] Al Jam'iyatul Washliyah: Sejarah Sosio-Religius dan Intelektual Periode Awal," dalam Syaiful Akhyar Lubis (ed), Peran Moderasi al-Washliyah, cet.1, Medan: Univa Press, 2008.

[32] Bruinnesen, Martin Van, Kitab Kuning: Pesantren dan Tarekat; Tradisi-tradisi Islam di Indonesia, cet. 1, Bandung: Mizan, 1995.

[33] NU: Tradisi, Relasi-relasi Kuasa, Pencarian Wacana Baru, terj. Farid Wajdi, cet.1, Yogyakarta: LKIS Pustaka Pelajar, 1994

[34] Caar, Edward Hallet, What is Histrory, Australia: Penguin Books, 1964.

[35] Daya, Burhanuddin, Gerakan Pembaharuan Pemikiran Islam, Kasus Sumatera Thawalib, Yogyakarta, Tiara Wacana 1990.

[36] Hasanuddin, Chalijah, Al Jam'iyatul Washliyah: Api dalam Sekam di Sumatera Timur 1930-1942, Bandung: Pustaka 1998.

[37] Ibn Khaldun, Al alIamah Abdurrahman bin Muhammad, Mukaddimah Ibnu Khaldun, terj. Masturi Irham dkk., cet.1, Jakarta: Pustaka al Kautsar, 2011.

[38] Kartodirjo, Sartono, Pendekatan Ilmu Sosial dalam Metodologi Sejarah, Jakarta: Gramedia, 1992.

[39] Mu'arif, Modernisasi Pendidikan Islam: Sejarah dan Perkembangan Kweekschool Moehammadiyah 1923-1931, cet.1, Yogyakarta: Suara Muhammadiyah, 2012.

[40] Pasha, Mustafa Kamal dan Ahmad Adaby Darban, Muhammadiyah sebagai Gerakan Islam, Yogyakarta: Pustaka SM, 2005.

[41] Pulungan, Abbas, Sejarah Dinamika Jam'iyyah Nahdlatul Ulama di Sumatera Utara, Medan: Puslit IAIN Sumatera Utara, 2009.

[42] Zaini, Achmad, Kyai Haji Abdul Wahid Hasyim: His Contribution to Muslim Educational Reform and Indonesia Nationalism during the Twentieth Century,Yogyakarta: Titian Ilahi Press, 1998 